\title{
Efektivitas Model Pembelajaran Multiliterasi Terhadap Literasi Sains Siswa Kelas V Sekolah Dasar
}

\author{
Yuyu Yuliati ${ }^{*}$, Budi Febriyanto ${ }^{2}$, Dudu Suhandi Saputra ${ }^{3}$ \\ 1 Universitas Majalengka, Majalengka, Indonesia \\ 2 Universitas Majalengka, Majalengka, Indonesia \\ 3 Universitas Majalengka, Majalengka, Indonesia \\ *Corresponding author: yuyuliati74@gmail.com
}

\begin{abstract}
The reality shows that the literacy ability of elementary school students is still low. The low ability of scientific literacy is suspected to be related to the science learning process that has not provided opportunities for students to develop the ability to act and reason critically so that students are unable to relate the scientific knowledge they learn to the phenomena that occur. To improve this situation, teachers should design innovative learning that can improve students' scientific literacy skills. This study aims to determine the effectiveness of the multiliteracy learning model on the scientific literacy ability of elementary school students. This study uses a quasi-experimental method with a pretest-posttest control group design. The research was conducted in Class $V$ of SD Negeri Cijurey II and SD Negeri Cibentar III. The results showed that there were differences in scientific literacy skills between students with multiliterate learning and students with conventional learning. Thus, the multi-literacy learning model is effective in improving the scientific literacy skills of elementary school students. Keywords: learning model; multiliteracy model, science literacy
\end{abstract}

\section{ABSTRAK}

Realitas menunjukan bahwa kemampuan literasi siswa sekolah dasar masih rendah. Rendahnya kemampuan literasi sains ini ditengarai berhubungan dengan proses pembelajaran sains yang belum memberikan peluang bagi siswa untuk mengembangkan kemampuan berbuat dan bernalar secara kritis, sehingga siswa tidak mampu mengaitkan pengetahuan sains yang dipelajarinya dengan fenomena-fenomena yang terjadi. Untuk memperbaiki keaadaan ini guru hendaknya mendesain pembelajaran inovatif yang mampu meningkatkan kemampuan literasi sains siswa. Penelitian ini bertujuan untuk mengetahui efektivitas model pembelajaran multiliterasi terhadap kemampuan literasi sains siswa sekolah dasar. Penelitian ini mennggunakan metode kuasi eksperimen dengan desain pretest posttest control group design. Penelitian dilaksanakan di Kelas V SD Negeri Cijurey II dan SD Negeri Cibentar III. Hasil penelitian menunjukan terdapat perbedaan kemampuan literasi sains antara siswa dengan pembelajaran multiliterasi dan siswa dengan pembelajaran konvensional. Dengan demikian model pembelajaran multilterasi efektif meningkatkan kemampuan literasi sains siswa sekolah dasar.

Kata Kunci: literasi sains; model multiliterasi; model pembelajaran

\section{Pendahuluan}

Sains merupakan pengetahuan ilmiah yang diperoleh dari hasil penyelidikan mengenai fenomena yang terjadi di alam. Sains tidak hanya mengajarkan siswa mengenai fakta, teori, atau fungsi alam bagi manusia, tetapi juga mengajarkan bagaimana cara para ahli sebelumnya mendapatkan konsep mengenai alam tersebut, serta bagaimana cara kita mengadopsi sikap ilmiah para ilmuan dalam mendapatkan suatu teori. Pada aplikasinya pendidikan sains bertujuan untuk membangun literasi sains siswa yang berarti bahwa melalui proses pendidikan sains siswa memahami apa yang dipelajari serta dapat mengaplikasikannya dalam kehidupan sehari-hari. Hal tersebut sesuai dengan penjelasan Harlen (2004: 70), The overall goal of science education for all children is to develop scientific literacy, meaning a level of competence in understanding and using knowledge of science that is needed for functioning effectively as a member of 
society. Literasi sains dapat didefinisikan sebagai pemahaman atas sains dan prosesnya, serta aplikasinya bagi kebutuhan masyarakat. Mengamati realitas pembelajaran sains saat ini, kecenderungan kemampuan literasi sains siswa masih rendah, menurut survey PISA pada tahun 2018 skor kemampuan Membaca, Matematika, dan Sains siswa 371, 379, dan 396 memposisikan Indonesia pada posisi ke 75 dari 80 negara yang mengikuti tes dan survey (OECD, 2019). Selanjutnya, TIMSS menunjukan bahwa skor rata-rata pada matematika dan science siswa Indonesia adalah 397 dengan posisi untuk bidang matematika pada level 45 dari 50 negara dan science berada di level 45 dari 48 negara peserta peniliaian dan survey (TIMSS dan PIRLS, 2015). Pada hal ini siswa kesulitan memahami dan menginterpretasi gambar terkait konsepsi saintifik fisika dan ilmu hayat selain itu kemampuan siswa dalam penerapan dan penalaran saintifik juga masih lemah. Meskipun siswa menunjukkan pemahaman terhadap soal yang terkait dengan kehidupan sehari-harinya, siswa kurang memahami konsep secara bermakna dan masih terpaku pada penjelasan pada buku teks.

Rendahnya kemampuan literasi sains ditengarai berhubungan dengan proses pembelajaran sains yang belum memberikan peluang bagi siswa untuk mengembangkan kemampuan berbuat dan bernalar secara kritis, sehingga siswa tidak mampu mengaitkan pengetahuan sains yang dipelajarinya dengan fenomena-fenomena yang terjadi. Menurut Sumartati (2010) rendahnya kemampuan literasi sains siswa Indonesia diantaranya disebabkan oleh pembelajaran yang masih terpusat pada guru (teacher centered), rendahnya sikap positif siswa dalam mempelajari sains, terdapat beberapa kompetensi yang tidak disukai siswa terkait konten, proses dan konteks. Selanjutnya menurut Norris \& Pillips (2003) rendahnya kemampuan literasi sains siswa dapat disebabkan karena kebiasaan pembelajaran sains yang masih bersifat konvensional serta mengabaikan pentingnya kemampuan membaca dan menulis sains sebagai kompetensi yang harus dimiliki siswa. Pada penelitian lain juga menunjukan hal yang tidak jauh berbeda bahwa menurut Fuadi, H., dkk (2020) Rendahnya kemampuan literasi yang dimiliki siswa dipengaruhi oleh pemilihan buku ajar, miskonsepsi, pembelajaran yang tidak kontekstual, dan kemampuan membaca peserta didik. Selain itu factor penyebab rendahnya kemampuan literasi sains juga dikarenakan siswa tidak terbiasa mengerjakan soal tes literasi sains atau masalah yang berhubungan dengan keterampilan proses sains yang merupakan bagian utama literasi sains (Winata, A., Cacik, S., Seftia, I., 2016). Kondisi ini menuntut adanya pembenahan dalam pembelajaran sains untuk mewujudkan pembelajaran yang lebih efektif.

Pendidik sudah selayaknya mempraktekan proses pembelajaran yang menitik beratkan pada pengembangan literasi sains yang utuh hal ini sesuai dengan pendapat Erdogan and Ciftci (2017) menjelaskan bahwa Teachers practicing education program should be informed about studies on developing scientific literacy levels of students, It should be observed during education process whether students learn reading, writing and using scientific terms properly or not which are taught according to the existing science and technology program. Salah satu alternatif pembelajaran bermakna yang dapat diterapkan untuk mengembangkan kemampuan literasi sains siswa adalah model pembelajaran multiliterasi. Pembelajaran multiliterasi adalah pembelajaran yang menggunakan keterampilan berbahasa untuk mempelajari dan membentuk pemahaman yang kompleks atas pengetahuan yang berhubungan dengan ilmu lainnya dalam proses kegiatan inkuiri serta sebagai sarana membangun pengetahuan (Dafit, 2017). Dengan kata lain, Melalui model pembelajaran multiliterasi ini memungkinkan siswa meningkatkan 
kemampuan berpikir kritis, pemahaman konseptual, kolaboratif, dan komunikatif melalui penggunaan alat dan berbagai macam sumber belajar, ilmu pengetahuan lainnya serta kegitan membaca secara efektif. Menurut Olge dalam Abidin (2013) karakteristik Model Pembelajaran Multiliterasi di SD/MI diantaranya yaitu mampu menghubungkan materi yang dipelajari dengan apa yang telah siswa ketahui, Pembelajaran multiliterasi senantiasa menghubungkan materi yang dipelajari dengan kehidupan nyata dan isu-isu kontemporer, model multiliterasi senantiasa melibatkan siswa untuk terlibat aktif dalam mengajukan pertanyaan dan membuat simpulan, memberikan banyak peluang untuk mempelajari materi pembelajaran secara mendalam sekaligus menyimpan pemahaman yang diperoleh dalam memori jangka panjang siswa, pembelajaran multiliterasi senantiasa menggunakan kerja kolaboratif dalam mengonstruksi makna dan sudut pandang atas materi yang sedang dipelajari, melibatkan berbagai ragam belajar sebagai sarana mengonstruksi pemahaman baru, dan melibatkan banyak strategi belajar. Beberapa penelitian yang menunjukan keberhasilan penerapan pembelajaran multiliterasi diantaranya, seperti penelitian yang dilakukan oleh Dafit, F,.dkk (2018) pembelajaran multiliterasi efektif meningkatkan kemampuan berpikir kritis siswa sekolah dasar. Penelitian Ginanjar, A.Y \& Widayanti, W (2018) menunjukan hasil bahwa model pembelajaran multiliterasi mampu meningkatkan kemampuan literasi matematis siswa SD. Penelitian Febriyanto \& Yanto (2019) menunjukkan bahwa model pembelajaran multiliterasi dapat meningkatkan pemahaman konsep siswa. Selanjutnya model pembelajaran multiliterasi juga terbukti mampu memperbaiki berbagai keterampilan berbahasa siswa seperti penelitian Susilo, S.V \& Randiati, T (2018) model multiliterasi mampu meningkatkan keterampilan menulis karangan peruasi pada mata pelajaran bahasa Indonesia. Penelitian Dafit, F (2017) pembelajaran multiliterasi dapat dipertimbangkan sebagai salah satu model pembelajaran dalam upaya meningkatkan kemampuan membaca pemahaman siswa SD. Penelitian Saputra, H \& Supriyono. (2017) model multiliterasi efektif meningkatkan kemampuan menulis narasi siswa sekolah dasar. Selanjutnya penelitian Suparya, I.K (2019) model multiliterasi saintifik berbasis kearufan local mampu meningkatkan literasi sains siswa sekolah dasar.

Berdasarkan pemaparan di atas, peneliti akan melaksanakan penelitian untuk mengetahui efektivitas pembelajaran multiliterasi.

\section{Metode Penelitian}

Metode penelitian yang digunakan dalam penelitian ini menggunakan Model kuasi eksperimen (Quasi Experimental Design) yang bertujuan untuk mengetahui efektivitas model pembelajaran Multiliterasi terhadap kemampuan literasi sains siswa Sekolah Dasar. Desain penelitian yang digunakan dalam penelitian ini yaitu Pretest Posttest Control Group Design (Creswell, J., 2008). Dalam desain penelitian ini terdapat dua kelas yaitu select control group dan select experimental group. Kelas ekperimen diberi perlakuan berupa pembelajaran multiliterasi, sedangkan kelas kontrol menggunakan bukan pembelajaran multiliterasi yaitu pembelajaran yang biasa sehari-hari dilakukan oleh siswa. Kedua kelas diberikan pre test dan post test dengan menggunakan instrument test yang sama. Hasil tes dari kedua kelas tersebut dianalisis dan dideskripsikan untuk melihat sejauh mana peningkatan kemampuan literasi sains sisewa SD melalui pembelajaran multiliterasi. Penelitian dilaksanakan di SD Negeri Cijurey II dan SD Negeri Cibentar III. Adapun subjek penelitiannya adalah siswa Sekolah 
Dasar Kelas V. Pengambilan sampel pada penelitian ini menggunakan teknik purposive sampling yaitu pengambilan subjek berdasarkan tujuan atau disesuaikan dengan tujuan penelitian (Sukmadinata, 2010: 254). Pada penelitian ini, kelas V SD Negeri Cijurey II ditentukan sebagai kelas eksperimen dengan jumlah siswa sebanyak 24 orang siswa. Sedangkan kelas VSD Negeri Cibentar III ditentukan sebagai kelas kontrol dengan jumlah siswa sebanyak 26 orang siswa.

\section{Hasil dan Pembahasan}

Data yang dianalisis dalam penelitian ini adalah skor pretest, postes, dan n-gain kemampuan literasi sains siswa sekolah dasar untuk kelas control dan kelas eksperimen. Sebelum dilakukan uji hipotesis, terlebih dahulu dilakukan uji prasyarat data terhadap variable penelitian kemampuan literasi sains. Adapun uji prasyarat data meliputi uji normalitas dan uji homogenitas yang dilakukan pada data pretes dan postes baik pada kelas eksperimen maupun kelas control. Berdasarkan uji normalitas data pretes maupun postes kemampuan literasi sains siswa kelas ekperimen dan kelas control dinyatakan normal. Selanjutnya, berdasarkan hasil uji homogenitas data pretes maupun postes kelas eksperimen dan kelas control diketahui homogen. Langkah analysis data selanjutnya yaitu melakukan uji perbedaan dengan menggunakan Analisis Independent Sample T Test. Berdasarkan hasil uji perbedaan diperoleh nilai signifikansi 0,001 lebih kecil dari 0,005, sehingga dapat disimpulkan bahwa terdapat perbedaan kemampuan literasi sains antara siswa kelas eksperimen yang menggunakan model pembelajaran multiliterasi dengan kelas control yang menggunakan model pembelajaran konvensional. Artinya bahwa model pembelajaran multiliterasi efektif meningkatkan kemampuan literasi sains siswa sekolah dasar.

Berdasarkan hasil analisis terhadap berbagai temuan hasil penelitian di atas, menunjukan bahwa model pembelajaran multiliterasi lebih efektif meningkatkan kemampuan literasi sains siswa sekolah dasar dibanding dengan pembelajaran konvensional, hasil penelitian ini relevan dengan penelitian yang dilakukan oleh Suparya, I.K (2019) yang mana pada penelitiannya juga menunjukan keefektifan model multiliterasi terhadap peningkatan kemampuan literasi sains siswa sekolah dasar. Keberhasilan penelitian ini tentunya tidak terlepas dari penerapan pembelajaran yang secara efektif mampu melibatkan siswa secara aktif dalam proses pembelajaran baik dalam berbuat, bernalar, dan mengembangkan kemampuan berpikir tingkat tinggi melalui penerapan keterampilan multiliterasi secara optimal, Abidin (2015) menyebutkan bahwa pembelajaran multiliterasi merupakan pembelajaran yang mengoptimalkan keterampilan-keterampilan multiliterasi dalam mewujudkan pembelajaran yang efektif.

Jika ditinjau dari langkah pembelajaran multiliterasi, langkah yang pertama yaitu siswa memahami dan menemukan permasalahan. Pada tahap ini siswa belajar tentang bagaimana permasalahan tersebut terjadi dan apa yang menyebabkan permasalahan tersebut dapat terjadi. Tahap menentukan masalah pada model multiliterasi mampu mengembangkan kemampuan menganalisis data dan mengubah dari representasi visual ke representasi lisan. Kemampuan tersebut terdapat pada kompetensi literasi sains yaitu kompetensi menginterpretasikan data dan bukti ilmiah. Pada tahap ini, siswa juga mengembangkan kemampuan literasi sains. Tahapan selanjutnya adalah tahap mencatat informasi dan menentukan cara penyelesaian masalah, tahapan ini dilalui siswa melalui kegiatan percobaan 
dan pengamatan demi membuktikan hipotesis yang telah mereka ajukan sebelumnya, Tahap mengumpulkan dan mencatat data pada penelitian ini diyakini dapat mengembangkan pengetahuan konten, prosedural serta kompetensi menginterpretasikan data dan bukti ilmiah dalam domain kompetensi literasi sains. Karena melalui kegiatan pengamatan atau percobaan, siswa melatih pengetahuan konten dan proseduralnya. Selain itu, kegiatan tersebut juga melatih kemampuan siswa mengubah data dari satu representasi ke representasi lain pada kompetensi menginterpretasikan data dan bukti ilmiah. Tahapan menganalisis data membawa siswa untuk meningkatkan kemampuan membaca dan menulis. Hal ini karena siswa perlu memahami pertanyaan yang diarahkan guru untuk memecahkan masalah melalui teks. Lalu siswa harus pandai menuangkan katakatanya dalam bentuk tulisan untuk menuliskan cara memecahkan masalah yang tepat (Saputra, \& Susilo; 2019), (Pramujiono, Saputra, \& Rachmadtullah; 2020).

\section{Kesimpulan}

Berdasarkan hasil penelitian dan pembahasan dapat disimpulkan bahwa model pembelajaran multiliterasi efektif dalam meningkatkan kemampuan literasi sains siswa sekolah Dasar. model pembelajaran multiliterasi memiliki dampak positif pada siswa terhadap antusiasme untuk belajar khususnya pada pembelajaran sains karena merumuskan teknik pembelajaran sangat menyenangkan sehingga siswa tidak merasa bosan saat mempelajari materi.

\section{Daftar Pustaka}

Abidin, Y. (2016) . Revitalisasi Penilaian Pembelajaran dalam Konteks Pendidikan Multilitreasi Abad ke-21.Bandung: Refika Aditama.

Abidin, Y. (2015) Pembelajaran Multiliterasi: Sebuah Jawaban atas Tantangan Pendidikan Abad Ke21 dalam Konteks Keindonesiaan: Bandung: Refika Aditama.

Baguley, M., Pullen, D. L \& Short, M. (2010). Multiliteracies and the New World Order. IGI GLOBAL Disseminator of Knowledge, hlm 1-17.

Bybee, R. W. (2009). PISA'S 2006 Measurement of Scientific Literacy: An Insider's Perspective for the U.S. A Presentation for the NCES PISA Research Conference. Washington: Science.

Cavas, P., Ozdem, Y., Cavas, B., and Ertepinar, H. (2013). Turkish Pre-Service Elementary Science Teachers' Scien- tific Literacy Level and Attitudes toward. Science. Science Education International 24, 383-401

Creswell, J. (2008). Educational Research: Planning, Conducting, and Evaluating Quantitative and Qualitative Research, 3rd Edition.New Jersey: Person Education Inc.Morroco, et. al. (2008). Supported Literacy for Adolescements: Transforming Teaching and Content Learning for the 21 st Century. Education Development Center All Right Resrved: Published by Jossy-Bass.

Dafit, F,.dkk. (2018). Efektivitas pembelajaran multiliterasi terhadap kemampuanberpikir kritis siswa sekolah dasar pada materi ekosistem. JMIE. 2(2). 181-193.

Dafit, F. (2017). Implementasi model multiliterasi pada proses pembelajaran membaca pemahaman siswa kelas IV Sekolah dasar. Jurnal sekolah. 1(2), 53-59.

Erdogan, I. and Ciftci, A. (2017). Investigating the Views of Pre-Service Science Teachers on. STEM Education Prac- tices. International Journal of Environmental and Science toward 
STEM. EURASIA Journal of Mathematics Science and Technology Education 13, 1189 1211

Febriyanto, B \& Yanto, A. (2019). Penerapan Model Pembelajaran Multilierasi Informasi Untuk Meningkatkan Pemahaman Konsep Jual Beli. Jurnal Iqra': Kajian Ilmu Pendidikan. 4 (1). 42-55.

Ginanjar, A.Y \& Widayanti, W (2018). Penerapan model pembelajaran multiliterasi untuk meningkatkan kemampuan literasi matematis siswa di SD/MI. Jurnal keilmuan dan kependidikan dasar. 10 (2), 117-124.

Pramujiono, A., Saputra. D.S., \& Rachmadtullah, R. (2020).model pembelajaran multilitreasi berbantuan media bigbook terhadap kemampuan membaca pemahaman siswa kelas Vsekolah dasar. Jurnal pendidikan dasar, Vol. 11, No. 02

Saputra, D. S., \& Susilo, S.S. (2019). The Implementation of Multiliteration Learning Models in Improving The Ability of Reading Comprehension for Fifth Grade of Primary School. The 2nd PGSD UST International conferene on education. Vol. 2

Saputra, H \& Supriyono. (2017). efektivitas model pembelajaran multiliterasi alam meningkatka kemampuan menulis narasi dikelas $\mathrm{v}$ sekolah dasar. Jurnal ilmiah pendidikan guru sekolah dasar trilogy. 1(1), 33-39.

Suparya, I.K. (2019). Meningkatkan Literasi Sains Anak Sekolah Dasar Melalui Model Multiliterasi Saintifik Berbasis Kearifan Lokal. Prosiding Nasional jayapangus press. 154163.

Susilo, S.V \& Randiati, T. (2019). Penerapan model multiliterasi untuk meningkatkan keterampilan menulis karangan persuasi pada mata pelajaran bahasa Indonesia di sekolah dasar. Jurnal cakrawala pendas.5(1), 24-28.

Winata, A., Cacik, S., Seftia, I. (2016). Analisis kemampuan awal literasi sains mahasiswa pada konsep IPA. Education and Human Development Journal 1(1), 34-39. 